This is an electronic reprint of the original article. This reprint may differ from the original in pagination and typographic detail.

Author(s): Haapakoski, Minna; Kankainen, Annaliisa; Sjögren, Tuulikki

Title: $\quad$ Sickness Absence at Work and Supporting Being Present At Work, Among Employees Working Different Shifts in the Forest Industry

Year: $\quad 2015$

Version:

Please cite the original version:

Haapakoski, M., Kankainen, A., \& Sjögren, T. (2015). Sickness Absence at Work and Supporting Being Present At Work, Among Employees Working Different Shifts in the Forest Industry. Journal of Ergonomics, 5(3), Article 100141.

https://doi.org/10.4172/2165-7556.1000141

All material supplied via JYX is protected by copyright and other intellectual property rights, and duplication or sale of all or part of any of the repository collections is not permitted, except that material may be duplicated by you for your research use or educational purposes in electronic or print form. You must obtain permission for any other use. Electronic or print copies may not be offered, whether for sale or otherwise to anyone who is not an authorised user. 


\title{
Sickness Absence at Work and Supporting Being Present At Work, Among Employees Working Different Shifts in the Forest Industry
}

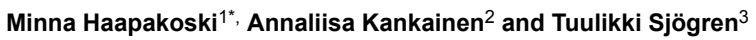 \\ ${ }^{1}$ Department of Health Sciences, University of Jyväskylä and University of Applied Sciences Jyväskylä, School of Health and Social Studies, Finland \\ ${ }^{2}$ Department of Mathematics and Statistics, University of Jyväskylä, Finland \\ ${ }^{3}$ Department of Health Sciences, University of Jyväskylä, Finland
}

*Corresponding author: Minna Haapakoski, Department of Health Sciences, University of Jyväskylä and University of Applied Sciences Jyväskylä, School of Health and Social Studies, Finland, Tel: 358503073066; E-mail: minna.haapakoski@jamk.fi

Received date: July 30, 2015; Accepted date: Setember 24, 2015; Published date: October 1, 2015

Copyright: (c) 2015 Haapakoski M, et al. This is an open-access article distributed under the terms of the Creative Commons Attribution License, which permits unrestricted use, distribution, and reproduction in any medium, provided the original author and source are credited.

\begin{abstract}
Objective: Shift work has negative effects on employee overall health, including sleep disorder, depressive symptoms, and cardiovascular and metabolic diseases. The association between shift work and the prevalence of sickness absence has been less studied. This study investigated sickness absence among employees working different work shift schedules in the forest industry.

Method: This descriptive cross-sectional study used employee $(\mathrm{N}=636)$ data from forest industry sick-leave registers. The study population $(n=280$; women $n=90$ and $m e n=189)$ worked five different shifts. Each of the five shifts was analyzed separately for sickness absence rate and the results were compared using independent and paired samples t-test.
\end{abstract}

Results: Persons working a three-shift rotation five days week (TAM35) had a significantly higher sickness absence rate $(P=0.001)$ than those working a two-shift rotation (TAM25). Among those working the three-shift rotation five days a week (TAM35) older male and female employees had more absences than their younger counterparts.

Conclusion: The three-shift model showed the highest association with sickness absence. This model does not support human physiological circadian rhythms. Of the five shift schedules studied, the day-shift (five days a week) and two-shift (five morning shifts and five evening shifts) models supported employee health.

Keywords: Well-being at work; Shift work; Sickness absence; Forest industry

\section{Introduction}

There is evidence that shift work negatively affects employee overall health. It has been shown to increase risk for cardiovascular diseases [1-3], metabolic disease, diabetes, overweight and obesity [4-7] and also depressive symptoms $[8,9]$. Sleep disorders, such as insomnia, poor sleep quality and daytime sleepiness is more common among shift workers than non-shift workers [10]. Shift and irregular work has acute effects on sleep and alertness, especially if work is done at night and/or the morning. The effects seem to linger and also extend to days off [11]. Drake et al. (2004) reported that employees who met the criteria for shift work sleep disorder had significantly higher rates of ulcers, sleepiness-related accidents, absenteeism and depression than shift workers who did not meet these criteria [12]. In women, shift work, especially at nights, was associated with risk for breast cancer [13]. In a review study, Saksvik et al. (2011) showed that adaptation to shift work was related to characteristics of the individual; for example, young age, male gender, high scores for flexibility and extraversion were association with higher shift work tolerance [14]. Prospective cohort and cross-sectional studies have shown that shift work is also associated with sickness absence and work ability [12,15-18].
Moreover, the results of these studies are conflicting. The research results on the links between different shift work schedules and sickness absences ranging from strong connection $[12,15,18-20]$ and or no links $[16,17]$. In addition, previous studies have focused more on health care workers [16-17,21-22] to the relative neglect of the industrial sector $[8,18]$.

Working time planning is important supporting the wellbeing of employees [20,23-26]. For example Hornberger \& Knauth [1995,1998] studies and Neil-Sztramko et al. (2014) review results showed that fastforward shift rotation has positive effect employee's health [24-26]. Employees asked about working a fast-forward rotating shift versus a long rotating shift reported that the former work shift pattern had a better effect on sleep, alertness, wellbeing at work and general health [23]. However, studies focusing on the effects of shift rotation on sickness absence are lacking, despite the fact that about $22 \%$ of the Finnish workforce are employed on shift work [19].

Shift work in the forest industry has been little investigated, although forest industry work is physically and psycho-socially demanding, as it includes a lot of repetitive loading and weightbearing, carrying to wood products and workers possibilities to influence the tasks they perform or how they perform them are low. Pahkini et al. (2010) found that varying the work shift pattern was a good way to support employee wellbeing at work in the paper industry. 
Citation: Haapakoski M, Kankainen A, Sjogren T (2015) Sickness Absence at Work and Supporting Being Present At Work, Among Employees Working Different Shifts in the Forest Industry. J Ergonomics 5: 141. doi:10.4172/2165-7556.1000141

Page 2 of 8

Employees asked about working a fast-forward rotating shift versus a long rotating shift reported that the former work shift pattern had a better effect on sleep, alertness, wellbeing at work and general health [23]. The aim of this study was to investigate sickness absence according to different work shifts models in the forest industry in Finland.

\section{Subjects and Methods}

This study was a descriptive cross-sectional investigation of a group of forest industry workers at two locations in Finland. The source population consisted of 636 forest industry employees [timber and wood products workers $(n=600)$ and office workers $(n=36)]$. The study group comprised 280 employees, of whom 90 were women (32\%) and 189 men 67\%, (Table 1). Average work experience was 18.1 (SD 2.3) years. The research project of which this study forms part has been described in an earlier article on the educational background and workload of forest industry employees. The educational level of the present participants was mainly vocational school or basic education [27]. Workload was assessed subjectively by an occupational physical activity questionnaire [28]. The three most common workload levels were "medium heavy work" (5.0 MET=Metabolic Equivalent), "physically light standing work or light work involving movement" (3.5 MET) and "other sedentary work" (2.5 MET) [28].

During the of 6.5-year study period January 2006-June 2012 sickness absence was $\leq 1.5 \%$ (of working time) for half of the employee sample ( $n=140$; cases), and was $>1.5 \%$ for the other half ( $\mathrm{n}=140$; controls). The sample $(\mathrm{N}=280)$ was randomly selected from the source population [Figure 1]. The study was approved by the ethical committee of the University of Jyväskylä, Finland (12.11.2012).

\begin{tabular}{|l|l|}
\hline Female & $90(32 \%)$ \\
\hline Male & $186(68 \%)$ \\
\hline Age,$\leq 45$ & $115(41)$ \\
\hline Age, $\geq 46$ & $164(59)$ \\
\hline Age, year & $47.3(27-64)$ \\
\hline 'For one employee information is missing \\
\hline
\end{tabular}

Table 1: Distribution for each variable, $\mathrm{N}$ (\% or min-max).

Data were gathered from sick-leave registers. The employer's registers gave detailed information on hours worked, overtime hours, sickness absence, accidents at work and other reasons for absence. There were five different work shift schedules [Table 2]. The tasks (forest industry factory work) were similar across the different shift schedules, except for the day shift (TAM15), which also included administrative tasks.

The register shows that many employees had worked several of these different schedules during the study period ( 6.5 years). Tables $3 \mathrm{a}$ and $3 \mathrm{~b}$ presents the numbers of employees working the different shift work schedules.

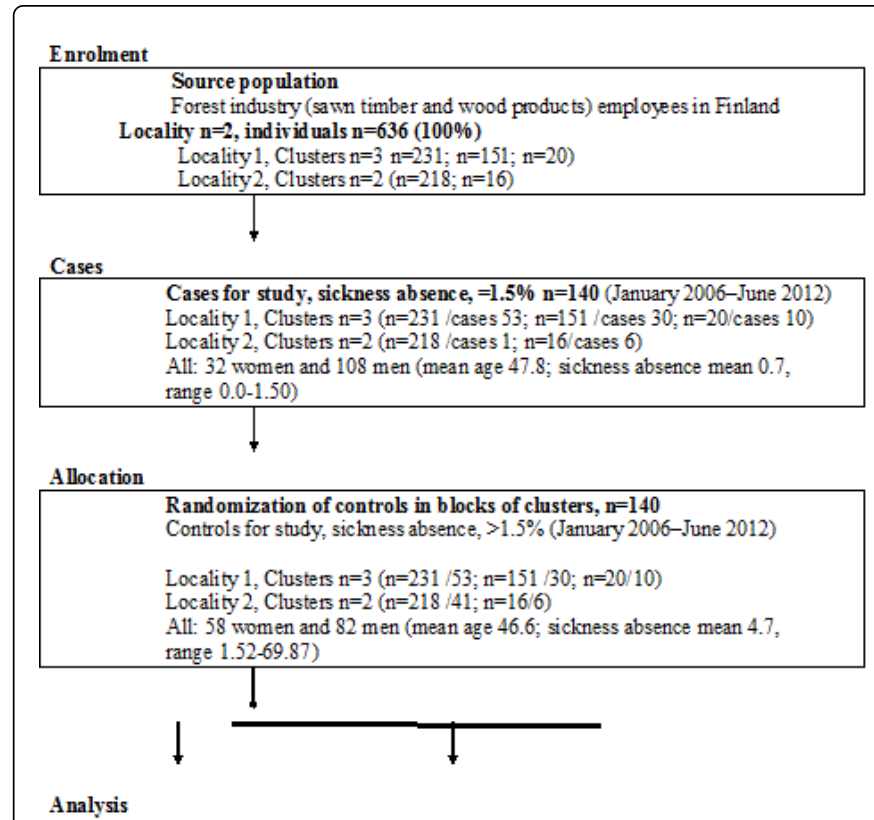

Individuals all $\mathrm{n}=\mathbf{2 8 0}$ (women $\mathrm{n}=90$ and men $\mathrm{n}=189$ ).

First: Sickness absence \% in five different shift work schedules were compared to the shift in pairs (10 comparison, for example, TAM15 compared TAMD5).

Second: Sickness absence \% different shift work schedules in women, men and different age $:=45$ and $=46$.

Figure 1: Study design and study subjects.

\begin{tabular}{|l|l|}
\hline \multicolumn{2}{|l|}{ Shift work schedules (1-5) } \\
\hline & Day shift (TAM15), five days a week (Monday-Friday) \\
\hline Every week & D-D-D-D-D-R-R \\
\hline Two-shift (TAM25), five days a week (Monday-Friday) \\
\hline Week 1 & D-D-D-D-D-R-R \\
\hline Week 2 & E-E-E-E-E-R-R \\
\hline Three-shift, five days a week (TAM35), five days a week (Monday-Friday) \\
\hline Week 1 & D-D-D-D-D-R-R \\
\hline Week 2 & N-N-N-N-N-R-R \\
\hline Week 3 & E-E-E-E-E-R-R \\
\hline Three-shifts six days a week (TAM36), six days a week (Monday to Saturday) \\
\hline Week 1 & D-D-E-E-N-N-R \\
\hline Week 2 & R-R-D-D-E-E-R \\
\hline Week 3 & N-N-R-R-D-D-R \\
\hline Week 4 & E-E-N-N-R-R-R \\
\hline Week 1 & D-D-E-E-N-N-R \\
\hline
\end{tabular}




\section{\begin{tabular}{l|l} 
Week 3 & N-N-R-R-R-R-R
\end{tabular}}

$D=$ Day shift 07:00-15:00 h; E=Evening shift 14:30-23:00 h; N=Night shift 22:00-06:00 h; R=Rest day.

Table 2: Five different shift work schedules (in Finnish “TyöAikaMuoto" TAM).

\begin{tabular}{|l|l|l|l|l|l|}
\hline $\begin{array}{l}\text { a) Shift } \\
\text { work } \\
\text { schedule }\end{array}$ & $\begin{array}{l}\text { Number of } \\
\text { employees }\end{array}$ & $\%$ & $\begin{array}{l}\text { b) Number } \\
\text { of shift work } \\
\text { schedules } \\
\text { worked }\end{array}$ & $\begin{array}{l}\text { Number of } \\
\text { employees }\end{array}$ & $\%$ \\
\hline TAM15* & 120 & 16.6 & 1 & 45 & 16.2 \\
\hline TAM25 & 139 & 19.2 & 2 & 92 & 33.1 \\
\hline TAM35 & 178 & 24.6 & 3 & 79 & 28.4 \\
\hline TAM36 & 122 & 16.9 & 4 & 53 & 19.1 \\
\hline TAM37 & 164 & 22.7 & all 5 & 9 & 3.2 \\
\hline Total & 723 & 100 & Total & $278^{1}$ & 100 \\
\hline 1 & &
\end{tabular}

${ }^{1}$ For two employees information on the shifts worked is missing.

*TAM15 day shift five days week, TAM25 two-shifts five days a week, TAM ${ }_{5}$ three-shifts five days a week, TAM36 three-shift six days a week and TAM37 three-shifts seven days a week.

Table 3: a) Shift work schedules number and percentage of employees working those schedules; b) Number and percentage of shift work schedules worked and by how many employees.

On every shift at least one person had no sickness absence hours while others had sickness absence that lasted almost the whole shift. Owing to these exceptional values, it was considered more useful to compare the sickness absence rates between the different shift work schedules using median rather than average values. Half of the employees were below and half above the median value. The median was highest in the three-shift schedule (TAM35) and lowest in the twoshift schedule (TAM25) [Table 4]. In the case group, in both the dayshift (TAM15) and three-shift six days a week (TAM36) schedules, the median was zero or almost zero.

\section{Statistical Analysis}

The sickness absence rate was calculated separately for each shift work schedule and schedules were compared using independent and paired samples t-test. Statistical analyses were performed using SPSS 22.00 .

The total number of working hours differed between the different shift work schedules, which mean that simple comparison is not possible. Therefore, sickness absence rates were constructed.

\begin{tabular}{|l|l|}
\hline Sickness & $100^{*}$ Sickness absence hours \\
\hline Absence rate & $\begin{array}{l}\text { Sickness absence+work accident+anything other reason for } \\
\text { sickness absence+hours worked }\end{array}$ \\
\hline
\end{tabular}

In this study, some employees had worked all five different shift work schedules (Table 2). Table 3 shows the number of employees in each schedule (left) and the number of different schedules worked by employee over the 6.5 year period. The most frequently worked schedule was the three-shift rotation, five days a week (TAM35) $n=178$ (24.6\%). Many employees had worked in several different shifts over the study period; only 45 had worked the same shift and nine had worked in all five schedules.

As only nine employees had worked all five schedules, analysis of variance for repeated measures cannot be applied, and as most of the employees had worked several different schedules shifts, the observations are not independent and therefore analysis of variance cannot be used in comparing the sickness rates across schedules. Instead t-tests are used. We compared every ten pairs of schedules using t-tests. In each pair of schedules, i.e., shift1 and shift2, we separate three groups of people: G1.2 comprises those who have worked both shift1 and shift2; group G1 comprises those who have worked shift1 but not 2; and group G2 comprises those who have worked shift 2 but not in shift1. We can then compare the sickness rates in shift1 and shift2 in group G1.2 using paired samples t-test and groups G1 and G2 using independent samples t-test. We also compared group G1.2 with groups G1 and G2 to see if these employees differed in their sickness absence rates when working both two schedules and when working only one of them.

Because we used a series of tests, we used the Bonferroni method and a significance level of $\mathrm{P}=0.005$, but results are also reported for $\mathrm{P}<0.05$.

\section{Results}

The results are presented for three different groups. First, the results are reported for the whole study group (cases and controls together); second, the results are reported by gender (women and men); and third, the results are reported by age group $(\leq 45$ and $\geq 46$ ).

\section{Sickness absence in the whole study group}

The variation in sickness absence rates is highest for the day-shift (TAM15) in both groups, but especially in the control group (see standard deviations table 4 and Figures $2 \mathrm{a}$ and $2 \mathrm{~b}$ ).

Among all the employees $(\mathrm{N}=280)$ working in the different schedules, those working the three-shift rotation five days a week (TAM35) show a statistically significantly higher sickness absence rate. For example, of all employees who worked the two-shift (TAM25) and three-shift (TAM35) rotations, those who worked the two-shift (TAM25) but not the three-shift (TAM35) rotation had a lower average sickness absence rate than those who worked the three-shift (TAM35) but not the two-shift (TAM25) rotation (independent samples t-test, $\mathrm{P}=0.001$ ). Those who worked only the two-shift TAM25 rotation had lower sickness absence rate than those who worked both shifts $(\mathrm{P}=0.002)$. The statistically significant differences between the different pairs of shifts are presented in more detail in table 5 .

\begin{tabular}{|l|l|l|l|l|l|l|}
\hline \multicolumn{2}{|c|}{} & TAM15 & $\begin{array}{l}\text { TAM2 } \\
\mathbf{5}\end{array}$ & $\begin{array}{l}\text { TAM3 } \\
\mathbf{5}\end{array}$ & $\begin{array}{l}\text { TAM3 } \\
\mathbf{6}\end{array}$ & $\begin{array}{l}\text { TAM3 } \\
\mathbf{7}\end{array}$ \\
\hline \multirow{2}{*}{ Cases } & $\mathrm{n}$ & 63 & 73 & 87 & 58 & 80 \\
\cline { 2 - 7 } & mean & 0.63 & 0.39 & 0.70 & 0.48 & 0.55 \\
\cline { 2 - 7 } & median & 0.00 & 0.00 & 0.56 & 0.01 & 0.13 \\
\cline { 2 - 7 } & $\begin{array}{l}\text { standard } \\
\text { deviation }\end{array}$ & 1.50 & 0.87 & 0.69 & 0.69 & 0.90 \\
\cline { 2 - 8 } & min & 0.00 & 0.00 & 0.00 & 0.00 & 0.00 \\
\hline
\end{tabular}


Citation: Haapakoski M, Kankainen A, Sjogren T (2015) Sickness Absence at Work and Supporting Being Present At Work, Among Employees Working Different Shifts in the Forest Industry. J Ergonomics 5: 141. doi:10.4172/2165-7556.1000141

Page 4 of 8

\begin{tabular}{|l|l|l|l|l|l|l|}
\hline & max & 10.15 & 5.10 & 3.57 & 2.59 & 4.88 \\
\hline \multirow{4}{*}{$\begin{array}{l}\text { Control } \\
\text { s }\end{array}$} & $\mathrm{n}$ & 57 & 66 & 91 & 64 & 84 \\
\cline { 2 - 7 } & mean & 8.65 & 6.04 & 7.61 & 7.80 & 5.05 \\
\cline { 2 - 7 } & median & 2.08 & 0.04 & 4.78 & 4.54 & 2.80 \\
\cline { 2 - 7 } & $\begin{array}{l}\text { standard } \\
\text { deviation }\end{array}$ & 17.53 & 14.39 & 9.86 & 13.41 & 7.07 \\
\cline { 2 - 7 } & min & 0.00 & 0.00 & 0.00 & 0.00 & 0.00 \\
\cline { 2 - 7 } & max & 100 & 95.22 & 75.44 & 87.93 & 36.23 \\
\hline \multirow{4}{*}{$\begin{array}{l}\text { All } \\
\text { [cases } \\
\text { and } \\
\text { controls } \\
\text { together } \\
\text { ) }\end{array}$} & mean & 120 & 139 & 178 & 122 & 164 \\
\cline { 2 - 7 } & median & 4.44 & 3.07 & 4.23 & 4.32 & 2.85 \\
\cline { 2 - 7 } & $\begin{array}{l}\text { standard } \\
\text { deviation }\end{array}$ & 12.73 & 10.26 & 7.53 & 10.36 & 5.56 \\
\cline { 2 - 7 } & min & 0.00 & 0.00 & 0.00 & 0.00 & 0.00 \\
\cline { 2 - 7 } & max & 100 & 95.22 & 75.44 & 87.93 & 36.23 \\
\hline
\end{tabular}

Table 4: Statistics for sickness absence rate (\%) in different work shift schedules separately for cases and controls and for all (cases and controls together).

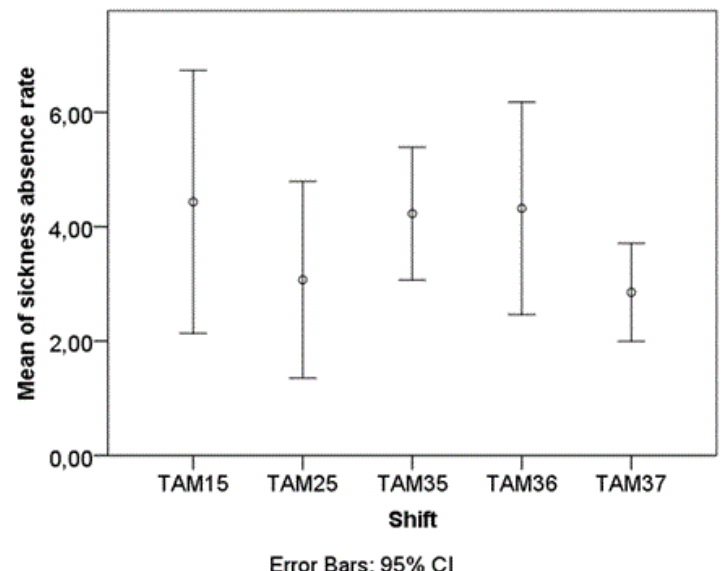

Figure 2a: Confidence intervals for the mean sickness absence rate in the different work shift schedules for cases and controls combined.

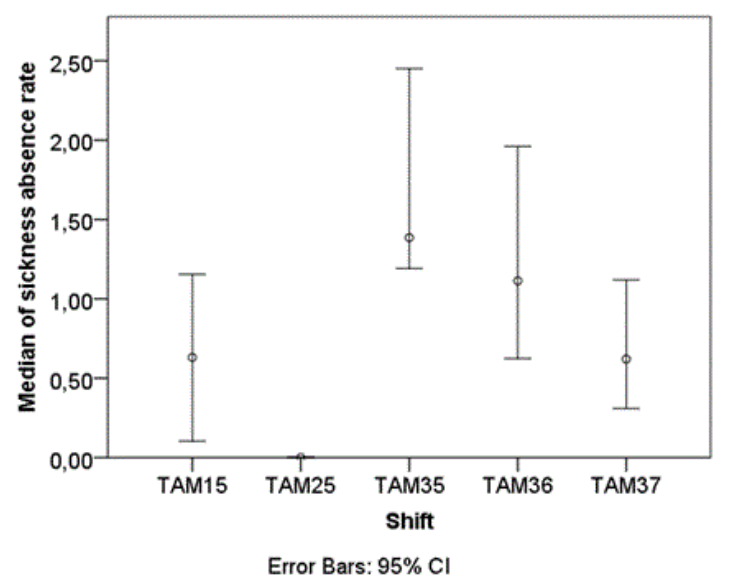

Figure 2b: Confidence intervals for the median sickness absence rate in the different work shift schedules for cases and controls combined.

\section{Sickness absence among female and male}

In this study, women had more sickness absence than men [Figure $3 \mathrm{a}$ and $3 \mathrm{~b}]$.

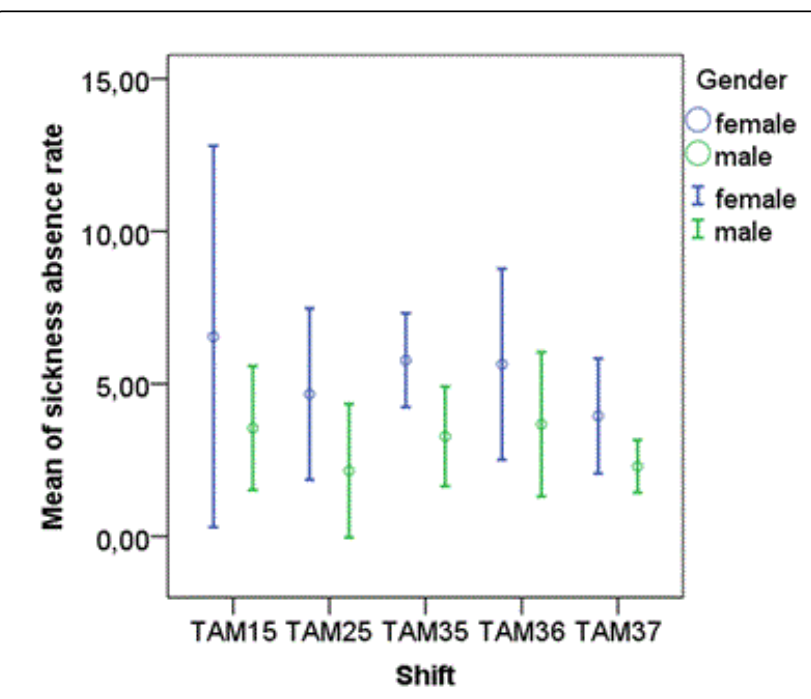

Error Bars: $95 \% \mathrm{Cl}$

Figure 3a: Confidence intervals for the mean sickness absence rates of men and women in the different work shift schedules for cases and controls combined. 


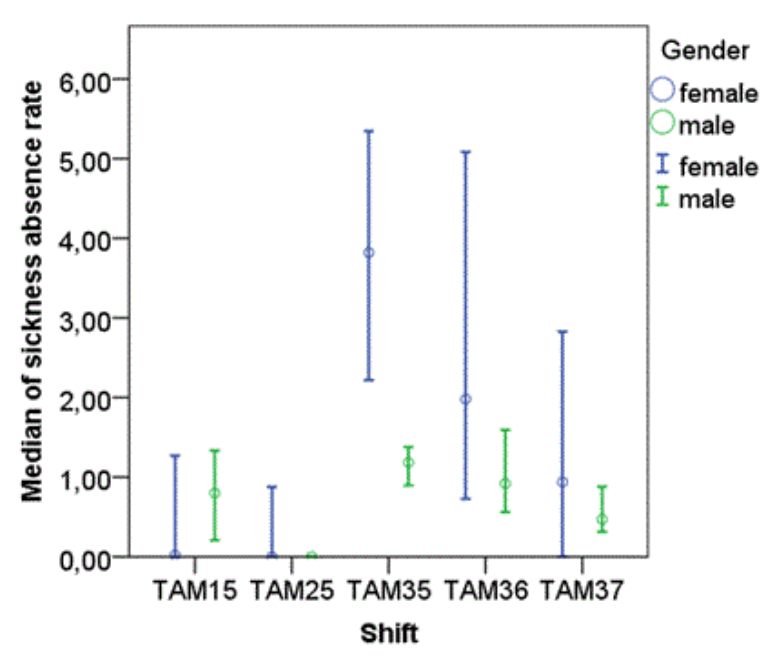

Error Bars: $95 \% \mathrm{Cl}$

Figure 3b: Confidence intervals for the median sickness absence rates of men and women in the different work shift schedules for cases and controls combined.

All the comparisons were made also for women and men separately. For women, sickness absence was higher among those women who only worked the three-shift (TAM35) rotation than for those who worked the day shift (TAM15, P $<0.001$ ) or two-shift (TAM25, $\mathrm{P}<0.001)$ but three-shift (TAM35) rotation. Women who only worked the two-shift (TAM25) rotation had a lower sickness absence rate than those who worked both the two-shift (TAM25) and three-shift (TAM35, $\mathrm{P}=0.001$ ) rotations. Women who worked both the three-shift rotation five days a week (TAM35) and three-shift rotation seven days a week (TAM37) rotations had a lower sickness absence rate in the three-shift rotation seven days a week (TAM37, $\mathrm{P}=0.002$ ). Women who only worked the three-shift rotation seven days a week (TAM37) also had a lower sickness absence rate than those who worked in both the three-shift rotation six days a week (TAM36) and three-shift rotation seven days a week (TAM37, $\mathrm{P}=0.003$ ). It seems that working a threeshift rotation five days a week (TAM35) increases the sickness absence rate, especially among women.

For men the only (almost) significant difference was that those who did not work the day-shift (TAM15) but only the two-shift (TAM25) rotation had a lower sickness absence rate than those who worked the day-shift (TAM15) but not the two-shift (TAM25, $\mathrm{P}=0.006$ ) rotation.

\section{Sickness absence in the younger $(\leq 45)$ and older $(\geq 46)$ age groups}

Of comparison by age group are shown in Figure $4 \mathrm{a}$ and $4 \mathrm{~b}$ ). For the age group $\leq 45$, the only difference was that those who worked the two-shift (TAM25) rotation but not three-shift rotation five days a week (TAM35) had lower sickness absence rate than those who worked the three-shift (TAM35) but not two-shift (TAM25, P=0.001) rotations. For the age group $\geq 46$ the only significant difference was that when working both the three-shift rotation five days a week (TAM35) and the three-shift rotation seven days a week (TAM37), the sickness absence rate was higher for the three-shift rotation five days a week (TAM35, $\mathrm{P}=0.002$ ). Some almost significant differences were observed: for example, those who worked the day-shift (TAM15) but not the three-shift rotation five days a week (TAM35) had a lower sickness absence rate than those who worked the three-shift (TAM35) rotation but not the day shift (TAM15, P=0.006). Again, working the three-shift rotation five days a week (TAM35) was associated with a higher sickness absence rate.

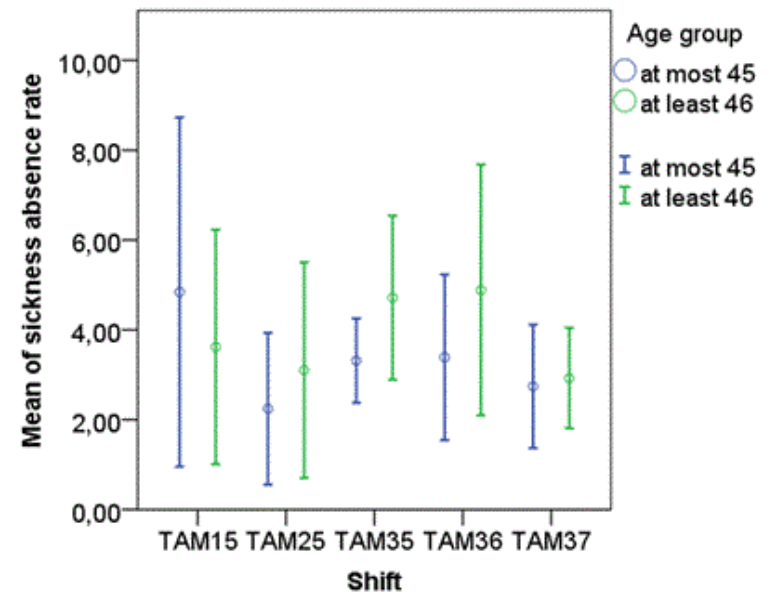

Error Bars: $95 \% \mathrm{Cl}$

Figure 4a: Confidence intervals for the mean sickness absence rates by age group and work shift schedule, cases and controls together.

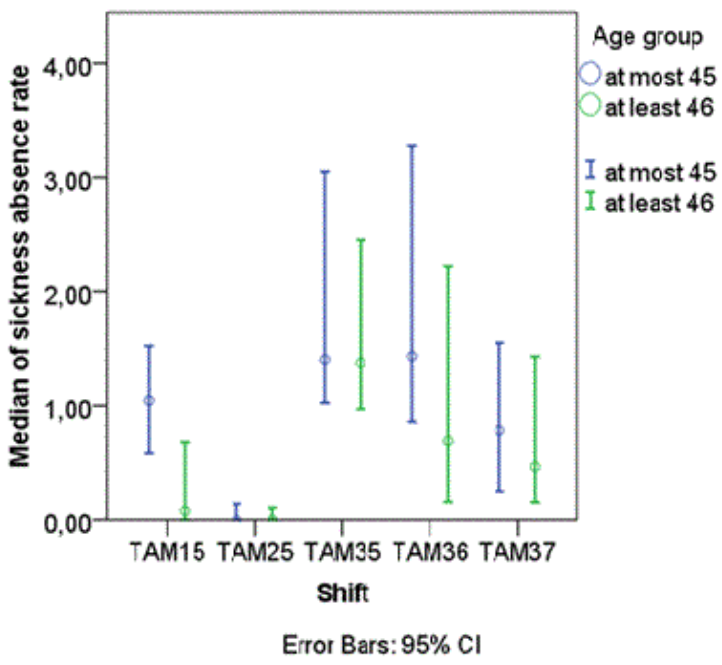

Figure 4b: Confidence intervals for the median sickness absence rates by age group and work shift schedule, cases and controls together.

Table 5 presents the results of the comparisons of the different age groups for women and men separately. The results are consistent with those reported above. The sample sizes of the groups are rather small so they are not reported here in any further detail.

Women over age 46 had more sickness absence than men in the same age group. A high frequency of absences was observed among women working the three-shift rotation five days a week (TAM35, 
Citation: Haapakoski M, Kankainen A, Sjogren T (2015) Sickness Absence at Work and Supporting Being Present At Work, Among Employees Working Different Shifts in the Forest Industry. J Ergonomics 5: 141. doi:10.4172/2165-7556.1000141

Page 6 of 8

independent samples t-test, P0.001). Men in the same age group also showed sickness absence when working the day shift (TAM15, independent samples t-test, P0.017). Men under age 45 had more sickness absence than women in the same age group.
Table 5 presents the results of the various comparisons between the shift work schedules in more detail. Comparisons were also made between women and men and by age group (under 45 years, over 46 years).

\begin{tabular}{|c|c|c|c|c|c|c|c|c|c|c|c|}
\hline \multirow[b]{2}{*}{ TAM15 } & \multirow{2}{*}{$\begin{array}{l}\text { Group } \\
\text { G15.25 }\end{array}$} & \multicolumn{2}{|c|}{ N All } & \multicolumn{2}{|c|}{ N Women } & \multicolumn{2}{|c|}{ N Men } & \multicolumn{2}{|c|}{$N \leq 45$} & \multicolumn{2}{|c|}{$N \geq 46$} \\
\hline & & 60 & & 24 & & 36 & $P=0.006$ & 25 & & 34 & \\
\hline and & G15 & 60 & & 12 & & 47 & G15-G25 & 32 & & 28 & \\
\hline TAM25 & G25 & 79 & & 27 & & 52 & & 24 & & 55 & \\
\hline TAM15 & G15.35 & 81 & $P=0.036$ & 29 & $P<0.001$ & 51 & & 36 & & 44 & $P=0.006$ \\
\hline and & G15 & 39 & G15-G35 & 7 & G15-G35 & 32 & & 21 & & 18 & G15-G35 \\
\hline TAM35 & G35 & 97 & & 40 & & 57 & & 34 & & 63 & \\
\hline TAM15 & G15.36 & 26 & & 9 & & 16 & & 13 & & 13 & \\
\hline and & G15 & 94 & & 27 & & 67 & & 44 & & 49 & \\
\hline TAM36 & G36 & 96 & & 33 & & 63 & & 33 & & 63 & \\
\hline TAM15 & G15.37 & 59 & & 21 & & 37 & & 28 & & 31 & \\
\hline and & G15 & 61 & & 15 & & 46 & & 29 & & 31 & \\
\hline TAM37 & G37 & 105 & & 36 & & 69 & & 36 & & 69 & \\
\hline TAM25 & G25.35 & 117 & $P=0.001$ & 43 & $P<0.001$ & 74 & & 40 & $P=0.001$ & 76 & $\mathrm{P}=0.027$ \\
\hline and & G25 & 22 & G25-G35 & 8 & G25-G35 & 14 & & 9 & G25-G35 & 13 & G25-G35 \\
\hline \multirow[t]{2}{*}{ TAM35 } & G35 & 61 & $P=0.002$ & 26 & $P=0.001$ & 34 & & 30 & & 31 & \\
\hline & & & $\begin{array}{l}\text { G25.35- } \\
\text { G25 }\end{array}$ & & $\begin{array}{l}\text { G25.35- } \\
\text { G25 }\end{array}$ & & & & & & \\
\hline TAM25 & G25.36 & 48 & & 20 & & 28 & & 16 & & 32 & \\
\hline and & G25 & 91 & & 31 & & 60 & & 33 & & 57 & \\
\hline TAM36 & G36 & 74 & & 22 & & 51 & & 30 & & 44 & \\
\hline TAM25 & G25.37 & 81 & & 34 & & 47 & & 27 & & 54 & \\
\hline and & G25 & 58 & & 17 & & 41 & & 22 & & 35 & \\
\hline TAM37 & G37 & 83 & & 23 & & 59 & & 37 & & 46 & \\
\hline TAM35 & G35.36 & 57 & & 28 & & 28 & & 19 & & 38 & \\
\hline and & G35 & 121 & & 41 & & 80 & & 51 & & 69 & \\
\hline TAM36 & G36 & 65 & & 14 & & 51 & & 27 & & 38 & \\
\hline TAM35 & G35.37 & 98 & $P=0.002$ & 43 & $P=0.002$ & 54 & & 37 & & 61 & $P=0.002$ \\
\hline and & G35 & 80 & G35.37 & 26 & G35.37 & 54 & & 33 & & 46 & G35.37 \\
\hline TAM37 & G37 & 66 & & 14 & & 52 & & 27 & & 39 & \\
\hline TAM36 & G36.37 & 110 & & 37 & $P=0.003$ & 72 & & 42 & & 68 & $P=0.050$ \\
\hline and & G36 & 12 & & 5 & $\begin{array}{l}\text { G36.37- } \\
\text { G37 }\end{array}$ & 7 & & 4 & & 8 & $\begin{array}{l}\text { G36.37- } \\
\text { G37 }\end{array}$ \\
\hline TAM37 & G37 & 54 & & 20 & & 34 & & 22 & & 32 & \\
\hline
\end{tabular}



group G1=Those who had worked shift1 but not shift2; and group G2 = Those who had worked shift 2 but not shift1. The sickness rates in shift1 and shift2 can be compared in group G1.2 using paired samples t-test and groups G1 and G2 using independent samples t-test. Group G1.2 was also compared with groups G1 and G2 to see if differences existed in the sickness absence rates between working both shifts and working just one of them.

Table 5: Comparisons of the work shift schedules for all employees combined, for women and men separately, and for the two age groups separately.

\section{Discussion}

The main findings of this study were that the work shift schedule associated with the highest sickness absence rate was the three-shift rotation five days week (TAM 35). This result was found for both sexes in both age-groups, in particular women over age 46, and men in both age groups. For both day shift (TAM15) and, in particular, two-shift (TAM25) work, the sickness absence rate was lower. It appeared that, when measured by the sickness absence rate, the day-shift (TAM15) and two-shift (TAM25) schedules best supported the present employees' health. According to the information received from the employer, employees who found shift work challenging were assigned to the day shift (TAM15).

In earlier studies have focused on the risk factors associated with shift work and the negative links between health and shift work $[1-4,7,9]$, whereas the association between shift work and sickness absence has not been systematically investigated and has remained unclear [8,16-17]. Our results are in line with those of Nakata et al., who reported that shift work was associated with higher sickness absence in the electronics sector among men [8], and with those of Tuchesen et al., who found that working evening may cause long-term sickness absence among employees in elderly care [17].

The present study supports earlier findings that the so called long work rotation (six or seven nights in a row) is a risk factor for employee health [23-26]. In order to get enough rest to return to work refreshed, a fast-forward rotating shift schedule has been recommended by researchers [26] and by the Finnish Occupational Health Institution [29]. Fast-forward rotation best supports the normal state of alertness and physiology in humans $[23,29]$. Hornberger and Knauth and Pahkini et al. also offer ergonomic recommendations for the design of shift systems. Regularity is also an important feature of an ergonomically designed work shift model [29].

This study showed that the work shift model that least supported physiological circadian rhythms (three-shift rotation five days a week, TAM35) was associated with a higher sickness absence rate (\%). It is possible that changing the order of the evening and night shifts would have a positive effect on the sickness absence rate, and hence general health. The resulting shift model would then support normal human physiology $[11,26]$ and the short work cycle (fast rotation of shifts: morning, morning, evening, evening, night, night, free, free) and fast shift model (only three or four night) be experienced positively [23-26]. It is known that work shift regularity is an important feature of an ergonomically designed work shift model [29].

Difficulties were experienced in this study in finding statistically appropriate and reliable methods for detecting the differences between sickness absences across the different shift work schedules, as many of the employees had worked several schedules but only nine employees had worked all five different shifts. Workers' tasks on the evening and night shift schedules did similar tasks, whereas day shift workers also did some administrative work. Consequently, if we had used variance analysis for repeated measures, a lot of information would have been lost. On the other hand, the fact that some employees had worked many shifts meant that the observations were not independent, and thus analysis of variance would not have yielded correct results. The personal tendency to being absent would also have been ignored. Therefore, we performed a series of tests comparing all the shift work schedules in pairs separately, which allowed us to test for differences between all the different employee groups (those who worked both schedules in the pair and those who worked one but not the other schedules in the pair). In so doing, we were able to use all the information (i.e., all employees) we had. The strength of this study was that the sickness absence follow-up period of 6.5 years was long enough. In other studies $[8,16]$ the follow-up periods has been much shorter, generally 1 or 1.5 years. Thus changes in the implementation of the workplace are easier to analyze, because the study design consists of the same employees in the organization.

Sickness absence covers a wide diversity of factors. The results of this study can partly be explained by reference to the mechanism of physiological circadian rhythms and how different shifts schedules support or impair general health $[11,20,26,29]$. Even if sickness absence behavior appears to be an individual behavior, it is often observed to reflect the functioning of the entire organization [23]. Therefore, supervisors and occupational health services should support healthy solutions to when work is done. This could mean better and more personalized work shift planning, as along with support of a healthy lifestyle [26]. In a review, Saksvik et al. review reported that young age, male gender, low scores on morningness, and high scores on flexibility and extraversion are related to higher shift work tolerance.

More high-quality research is needed that takes work schedules into account in the investigation of employee health and functioning and sickness absence, including, for example, personal factors such as whether the employee feels that $s / h e$ is a morning or an evening person. Shift work workload and the factors that support employee recovery both at work and during leisure time also merit further study.

\section{Conclusion}

In this study, the three-shift rotation five days a week (TAM35) showed the strongest association with the sickness absence rate, and can be concluded to least support the human physiological circadian rhythms. The day shift, five days a week (TAM15) and the two-shift rotation five morning shifts and five evening shifts; (TAM25) may better supports employee health, as measured by the sickness absence rate than the other shift models studied.

What is new? The shift work models used in the Finnish wood industry have been little investigated. This study confirms the view that a backward rotating three-shift schedule is associated with a higher sickness absence rate. 
Citation: Haapakoski M, Kankainen A, Sjogren T (2015) Sickness Absence at Work and Supporting Being Present At Work, Among Employees Working Different Shifts in the Forest Industry. J Ergonomics 5: 141. doi:10.4172/2165-7556.1000141

Page 8 of 8

\section{Acknowledgement}

We would like to thanks Arja Piirainen, PhD (University of Jyväskylä, Department of Health Sciences) for assistance with the research design work and data collection. Also we thank Arja Piirainen and Ari Heinonen, PhD (University of Jyväskylä, Department of Health Sciences) for commenting on the manuscript.

\section{References}

1. Boggild H, Knutsson A (1999) Shift work, risk factors and cardiovascular disease. Scand J Work Environ Health 25: 85-99.

2. Fujino $\mathrm{Y}$, Iso $\mathrm{H}$, Tamakoshi A, Inaba $\mathrm{Y}$, Koizumi A, et al. (2006) A prospective cohort study of shift work and risk of ischemic heart disease in Japanese male workers. Am J Epidemiol 164: 128-135.

3. Puttonen S, Harma M, Hublin C (2010) Shift work and cardiovascular disease - pathways from circadian stress to morbidity. Scand J Work Environ Health 36: 96-108.

4. Karlsson B, Knutsson A, Lindahl B (2001) Is there an association between shift work and having a metabolic syndrome? Results from a population based study of 27,485 people. Occup Environ Med 58: 747-752.

5. Kivimaki M, Virtanen M, Kawachi I, Nyberg ST, Alfredsson L, et al. (2015) Long working hours, socioeconomic status, and the risk of incident type 2 diabetes: A meta-analysis of published and unpublished data from222120 individuals. Lancet Diabetes Endocrinol 3: 27-34.

6. Gan Y, Yang C, Tong X, Sun H, Cong Y, et al. (2015) Shift work and diabetes mellitus: A meta-analysis of observational studies. Occup Environ Med 72: 72-78.

7. Wang F, Zhang L, Zhang Y, Zhang B, He Y, et al. (2014) Meta-analysis on night shift work and risk of metabolic syndrome. Obes Rev 15: 709-720.

8. Nakata A, Haratani T, Takahashi M, Kawakami N, Arito H, et al. (2004) Association of sickness absence with poor sleep and depressive symptoms in shift workers. Chronobiol Int 21: 899-912.

9. Chang MY, Tseng CH, Chiou YL (2014) The plasma concentration of copper and prevalence of depression were positively correlated in shift nurses. Biol Res Nurs 16: 175-181.

10. Yazdi Z, Sadeghniiat-Haghighi K, Loukzadeh Z, Elmizadeh K, Abbasi M (2014) Prevalence of Sleep Disorders and Their Impacts on Occupational Performance: A Comparison between Shift Workers and Nonshift Workers. Sleep Disord 2014: 870320.

11. Akerstedt T (1998) Shift work and disturbed sleep/wakefulness. Sleep Med Rev 2: 117-128.

12. Drake CL, Roehrs T, Richardson G, Walsh JK, Roth T (2004) Shift work sleep disorder: Prevalence and consequences beyond that of symptomatic day workers. Sleep 27: 1453-1462.

13. Pijpe A, Slottje P, van Pelt C, Stehmann F, Kromhout H, et al. (2014) The Nightingale study: rationale, study design and baseline characteristics of a prospective cohort study on shift work and breast cancer risk among nurses. BMC Cancer 14: 47.

14. Saksvik IB, Bjorvatn B, Hetland H, Sandal GM, Pallesen S (2011) Individual differences in tolerance to shift work-a systematic review. Sleep Med Rev 15: 221-235.
15. Ohayon MM, Lemoine P, Arnaud-Briant V, Dreyfus M (2002) Prevalence and consequences of sleep disorders in a shift worker population. J Psychosom Res 53: 577-583.

16. Tuchsen F, Christensen KB, Lund T (2008) Shift work and sickness absence. Occup Med (Lond) 58: 302-304.

17. Tuchsen F, Christensen KB, Nabe-Nielsen K, Lund T (2008) Does evening work predict sickness absence among female carers of the elderly? Scand J Work Environ Health 34: 483-486.

18. Safari S, Akbari J, Kazemi M, Mououdi MA, Mahaki B (2013) Personnel's health surveillance at work: Effect of age, body mass index, and shift work on mental workload and work ability index. J Environ Public Health 2013: 289498.

19. Perkiö-Mäkelä M, Hirvonen M (2013) Työ ja terveys Suomessa 2012 [Work and Health in Finland 2012]. Taulukkoraportti. Helsinki: Työterveyslaitos.

20. Pallesen S, Bjorvatn B, MagerÃ,y N, Saksvik IB, Waage S, et al. (2010) Measures to counteract the negative effects of night work. Scand J Work Environ Health 36: 109-120.

21. Karhula K, Puttonen S, Vuori M, Sallinen M, Hyvärinen H et al. (2011) Työstressin ja työaikajärjestelyjen vaikutukset uneen, kuormittumiseen ja toimintakykyyn terveydenhuoltoalan ammattilaisilla [the effect of longterm job-strain on sleep, perceived workload, functional capacity, cognitive functions and stress regulation in shiftworking females in the health care sectors]. Työterveyslaitos. Työympäristötutkimuksen raporttisarja 63.

22. Buss J (2012) Associations between obesity and stress and shift work among nurses. Workplace Health Saf 60: 453-458.

23. Pahkin K, Leppänen A, Kajosaari K, Ala-Laurinaho A, Welling I (2010) Työhyvinvoinnin kehittäminen ja sairauspoissaolojen hallinta paperiteollisuudessa. Työympäristötutkimuksen raporttisarja [The development of well-being at work and management of sickness absence in the paper industry] Työterveyslaitos 48

24. Hornberger S, Knauth P (1995) Effects of various types of change in shift schedules: a controlled longitudinal study. Work and stress 9:124-133.

25. Hornberger S, Knauth P (1998) Follow-up intervention study on effects of a change in shift schedule on shiftworkers in the chemical industry. International journal of industrial ergonomics 21:249-257.

26. Neil-Sztramko SE, Pahwa M, Demers PA, Gotay CC (2014) Healthrelated interventions among night shift workers: A critical review of the literature. Scand J Work Environ Health 40: 543-556.

27. Sjögren T, Haapakoski M, Haapaniemi V, Niku J, Kankainen A, et al. (2015) Factors explaining being present at work in the forest industry. Journal of Business and Economics.

28. Mälkiä E (1996) MET based questionnaire for the study of physical activity. In: Mälkiä E, Sihvonen S, editors. Assessment of function and movement. Selected papers. Third Nordic Symposium on physiotherapy. Jyväskylä: PainoPorras Oy 91-103.

29. Hakola T, Kalliomäki-Levanto (2010) Työvuorosuunnittelu hoitoalalla [work shift planning in health care]. Työterveyslaitos Helsinki: 25-26. 